Dr DRAGAN BOGETIĆ, naučni savetnik

Institut za savremenu istoriju

UDK 327(497.1:73)"196/197"

Beograd, Trg Nikole Pašića 11

339.92(497.1:73)"196/197"

\title{
JUGOSLOVENSKO-AMERIČKE NESUGLASICE OKO KONCEPTA NOVOG MEĐUNARODNOG EKONOMSKOG PORETKA*
}

\begin{abstract}
APSTRAKT: U članku je analizirano pogoršanje odnosa Jugoslavije i $S A D$ zbog različitog prilaza rešavanju nagomilanih svetskih ekonomskih problema i zbog različite strategije prema problemu premošćavanja sve većeg jaza između industrijski razvijenih zemalja i zemalja u razvoju. Budući da je Jugoslavija spadala u zemlje koje su bile nosioci brojnih inicijativa u pokretu nesvrstanih, pokrenutih u cilju radikalne transformacije postojećeg sistema međunarodnih ekonomskih odnosa - jugoslovenska politika je bila u direktnoj koliziji sa stavovima zvaničnika iz Vašingtona, koji su se oštro protivili ovakvim nastojanjima.
\end{abstract}

Ključne reči: Jugoslavija, SAD, zemlje u razvoju, razvijene zemlje, promene, Sever - Jug, ekonomski razvoj, nesvrstanost, diskriminacija

Tokom 70-ih godina prošlog veka međunarodni odnosi su obogaćeni jednom novom komponentom. Pored i dalje prisutne konfrontacije Istok Zapad, u prvi plan sve više izbija konfrontacija Sever - Jug, koja u nekim segmentima postaje najopasniji izvor zategnutosti u međunarodnim odnosima. Insistiranje nesvrstanih zemalja na ravnomernijoj raspodeli svetskog bogatstva i ublažavanju sve većeg jaza koji je delio bogati Sever od siromašnog Juga, naišlo je na izuzetno negativan prijem industrijski razvijenih zemalja. Iako su zapadne sile u prvom momentu ispoljile određenu kooperativnost $\mathrm{u}$ tom kontekstu, dalje forsiranje radikalnih ekonomskih zahvata na globalnom polju od strane nesvrstanih zemalja, rezultiralo je oblikovanjem strategije razvijenih zemalja koja je bila ne samo konzervativno-egoistična i odbranaška, nego i izrazito agresivna i ratoborna prema svim prota-

* Rad je deo projekta Srpsko društvo u jugoslovenskoj državi u 20. veku: između demokratije i diktature, (177016), koji je finansira Ministarstvo prosvete, nauke i tehnološkog razvoja Republike Srbije. 
gonistima suštinske transformacije postojećeg sistema međunarodnih odnosa. ${ }^{1}$

Američki predsednik Džerald Ford (Gerald Ford) i državni sekretar Henri Kisindžer (Henry Kissinger) oštro su napadali nesvrstane zemlje da su, u vreme kada blokovski antagonizmi između Istoka i Zapada slabe i kada je svet konačno ušao $u$ fazu detanta dveju supersila, formirale novi blok i dovele međunarodnu zajednicu na rub katastrofe. ${ }^{2}$ Jedinstven nastup nesvrstanih zemalja u OUN, višestruko povećanje cena nafte i zahteve zemalja u razvoju za uspostavljanjem novog međunarodnog ekonomskog poretka, okarakterisali su kao „tiraniju većine“ i pretili otvorenom primenom vojne sile ukoliko bi energetska situacija u svetu postala kritična za Zapad. $^{3}$

Pošto je Jugoslavija bila jedna od zemalja koje su posebno energično zagovarale ovu ideju, zvaničnici u Vašingtonu su sa sve većom podozrivošću preispitivali njenu nesvrstanu politiku. U Stejt departmentu je stav Jugoslavije, da je postojeći sistem međunarodnih ekonomskih odnosa skrojen po meri najbogatijih kapitalističkih zemalja i da zato reprodukuje odnose dominacije i eksploatacije imanentne samom biću kapitalizma, tumačen kao tipičan ideologizirani pogled komunističkih doktrinara, koji ne mogu u potpunosti da se oslobode i distanciraju od sovjetske propagande. ${ }^{4}$

Iako se može prihvatiti ocena da je jugoslovenski prilaz rešavanju glavnih problema $\mathrm{u}$ sferi međunarodnih ekonomskih odnosa bio u velikoj meri ideološki obojen, on, ipak, ni u kom slučaju nije bio istovremeno i kompatibilan sa strateškim opredeljenjima Sovjetskog Saveza, niti sa sadržinom opštih načela marksizma i lenjinizma koja su se ticala te problematike. Radilo se o relativno originalnom konceptu, čija su polazišta bila determinisana ranije formulisanim ekonomskim prioritetima nesvrstane politi-

${ }^{1}$ Dušan Nikoliš, SAD. Strategija dominacije, Beograd 1985; Ljubiša S. Adamović, Džon R. Lempi, Rasel O. Priket, Američko-jugoslovenski ekonomski odnosi posle Drugog svetskog rata, Beograd 1990.

${ }^{2}$ H. Kissinger, A Just Consensus, A Stable Order, A Durable Peace, An Address made before the 28th Session of United Nations General Assembly, September 24, 1973, „Department of State Bulletin“, October 15, 1973, p. 470; G. Ford, A Framework of International Cooperation, An Address made before the 29 th Session of the United Nations General Assembly, September 18, 1974., „Department of State Bulletin“, October 7, 1974, p. 446.

${ }^{3}$ Arhiv Jugoslavije (AJ), Kabinet Predsednika Republike (KPR), I-3-a/107-212. SAD i politika nesvrstavanja. Nastup Predsednika Forda na XXIX redovnom zasedanje GS UN; KPR, I-5-c/21. Sednica Saveta za nacionalnu bezbednost. Primena vojnih mera; KPR, I-5b/104-20. Kisindžerov intervju časopisu „Busines week“, januar 1975. Izjava o mogućoj upotrebi vojne sile; KPR, I-5-c/25. Kisindžerov govor u Misuriju, 15. maj 1975; Fordov govor na Universitetu Viskonsin instituta za svetske poslove u Milvokiju, 14. jul 1975.

${ }^{4}$ Foreign Relations of United States (FRUS), 1969-1976, Volume E-15, Part 1, Documents on Eastern Europe, 1973-1976, Yugoslavia, doc 69. 
ke: poštovanju principa nediskriminacije i obezbeđivanju ravnopravnog statusa svih država u međunarodnim ekonomskim odnosima, poštovanju suvereniteta i prava svih država da samostalno odlučuju o svim unutrašnjim pitanjima uključujući i pitanje nacionalizacije privrednih resursa $u$ vlasništvu stranih kompanija, obezbeđivanju međunarodne pomoći privrednom razvoju nedovoljno razvijenih zemalja bez političkih i ekonomskih uslovljavanja i uspostavljanju pravednih cena za izvozne proizvode zemalja u razvoju i za proizvode industrijski razvijenih zemalja (eliminisanje problema "makaza cena"). Jugoslovensko rukovodstvo pri tome je polazilo od stava da bez ekonomske emancipacije nesvrstanih zemalja nije mogućna ni njihova politička emancipacija. U tom duhu, Tito je još tokom Beogradskog samita nesvrstanih zemalja, septembra 1961, pokrenuo pitanje postizanja obostrano prihvatljivog sporazuma između velikih sila i novooslobođenih država oko preduzimanja mera za premošćavanje suprotnosti koje su stajale na putu unapređenja ekonomske saradnje između bogatog Severa i siromašnog Juga. Stoga je predložio sazivanje posebne svetske konferencije pod okriljem UN, posvećene isključivo međunarodnoj ekonomskoj problematici. Ta inicijativa je prihvaćena od nesvrstanih zemalja i uneta u Političku deklaraciju Beogradske konferencije. Borba za radikalnu transformaciju postojećeg sistema međunarodnih ekonomskih odnosa i za premošćavanje sve većeg jaza između razvijenih zemalja i zemalja u razvoju, nametnula se kao jedan od glavnih prioriteta buduće zajedničke akcije nesvrstanih zemalja. ${ }^{5}$

Inače, tokom Beogradskog samita postignut je i dogovor da se već naredne godine održi posebna konferencija nesvrstanih zemalja, posvećena isključivo ekonomskoj problematici. Taj dogovor bio je rezultat jugoslovenske inicijative za što širim ekonomskim povezivanjem vanblokovskih zemalja. ${ }^{6}$

Na toj konferenciji održanoj od 9. do 18. jula 1962. u Kairu uobličena je nova ekonomska platforma nesvrstanih zemalja i usvojen program

${ }^{5}$ Dragan Bogetić, Ljubodrag Dimić, Beogradska konferencija nesvrstanih zemalja 16. septembra 1961. Prilog istoriji Trećeg sveta, Beograd 2013.

${ }^{6}$ Obrazlažući potrebu tesnog povezivanja zemalja u razvoju, Tito je ukazao na diskriminaciju kojoj su te zemlje izložene u svetskoj trgovini zbog postojanja blokovskih organizacija: „Jednu od najvećih prepreka ekonomskoj povezanosti i saradnji predstavlja stvaranje Zajedničkog tržišta u Zapadnoj Evropi, a u najnovije vrijeme stvaranje Organizacije za ekonomsku saradnju i razvitak (OECD), koju danas neki počinju da nazivaju Atlantskom ekonomskom zajednicom, zatim stvaranje SEV-a, organizacije istočnoevropskih zemalja itd. Uslijed toga, zemlje koje su van tih organizacija, a to su u prvom redu neangažovane zemlje, nalaze se u diskriminisanom položaju. U daljoj perspektivi, to stanje može još i da se pogorša, i da se još štetnije odrazi na ekonomski razvitak neangažovanih zemalja, a i svih drugih. Zbog toga, a i iz mnogih drugih razloga, smatram da ekonomsku saradnju između nerazvijenih zemalja treba postaviti najšire, tako da ona obuhvati sve neangažovane zemlje, a i sve druge nedovoljno razvijene zemlje koje su na takvu saradnju spremne“. - Govor predsednika SFRJ Josipa Broza Tita u generalnoj debati, Skupovi nesvrstanih zemalja, Beograd 1974, 539. 
akcije, a sve u sklopu jedinstvenog cilja - radikalne transformacije međunarodnih ekonomskih odnosa. Da bi se to ostvarilo bilo je neophodno obezbediti organizovaniji i jedinstveniji nastup nesvrstanih zemalja na prevazilaženju ekonomskih problema koji su bili izvor njihove nestabilnosti, kako na unutrašnjem, tako i na spoljnom planu. Jugoslavija tu nije bila izuzetak i stoga je bila životno zainteresovana za obezbeđivanje ekonomskih mehanizama nesvrstanih zemalja koji bi smanjili ekonomsku zavisnost tih zemalja od svetskih sila, a istovremeno povećali njihovu privrednu saradnju. To je bio i jedini put ka suzbijanju sve pogubnijeg dejstva regionalnih organizacija zapadnih i istočnoevropskih država po ekonomske interese ostalih zemalja.

Poučeni negativnim iskustvom $\mathrm{u}$ pogledu reakcija zapadnih sila povodom održavanja Beogradskog samita prethodne godine, učesnici Kairske konferencije su, sa izuzetkom Kube, strogo vodili računa da svojim istupanjem ne iritiraju ponovo te sile, bez čije ekonomske pomoći nisu mogli obezbediti ni elementarne pretpostavke svog privrednog razvoja. Shodno tome, kritika kolonijalizma i neokolonijalizma, kao i zatvorenih ekonomskih integracija zapadnih država imala je samo uopšten i načelan karakter. Ideju o institucionalizaciji saradnje nerazvijenih zemalja i o neophodnosti formiranja tela koja bi obezbedila minimum koordinacije u tom kontekstu (koju su na Zapadu shvatali kao formiranje ekonomske organizacije nesvrstanih, uperene protiv ZET-a) - većina učesnika konferencije je odbacila. Slično je prošla i inicijativa jugoslovenskog predstavnika Vladimira Popovića da se kontinuirano delovanje zemalja učesnica Kairskog skupa omogući makar usvajanjem posebne odluke o dodeljivanju takve važne uloge „sponzorima konferencije“, dakle državama koje su je inicirale i organizovale. $\mathrm{Na}$ predlog Indije, usvojeno je uopšteno rešenje „da će sve zemlje učesnice sazivati posebne sastanke, seminare, sastanke grupa stručnjaka i konferencije". 7

Mada je skup u Kairu pokazao koliko je teško postići jedinstvo među nesvrstanim zemljama oko rešavanja nekih elementarnih pitanja njihovog ekonomskog razvoja, krajnji ishod tog skupa mogao se smatrati zadovoljavajućim. Zemlje učesnice su posle burne rasprave jednoglasno usvojile Deklaraciju, koja je imala karakter svojevrsnog ekonomskog programa budućih zajedničkih aktivnosti. Osnovu Deklaracije činio je jugoslovenski nacrt završnog dokumenta, obogaćen formulacijama koje su predložili predstavnici Indije, Egipta, Brazila i Pakistana. ${ }^{8}$ Mada se u Deklaraciji precizno ne pominje mogućnost formiranja stalnih mehanizama ekonomske saradnje zemalja $u$ razvoju, ove zemlje se pozivaju „da budu stalno $u$

\footnotetext{
${ }^{7}$ AJ KPR, I-4-a. Izveštaj o Kairskoj konferenciji i radu jugoslovenske delegacije.

${ }^{8}$ Isto. Rad na Završnom dokumentu; Sadržaj Deklaracije, 6-7, 12-18.
} 
međusobnom kontaktu“, da kroz tesnu saradnju rešavaju svoje ekonomske probleme, da u tu svrhu ako treba "uspostave pogodne institucije“ radi obezbeđenja kontinuiteta i efikasnosti akcije. Deklaracija obavezuje zemlje učesnice da na predstojećem zasedanju Generalne skupštine UN pokrenu inicijativu da se u dnevni red uvrsti i njihov zahtev da se naredne godine održi međunarodna konferencija o ekonomskom razvoju u okviru UN. ${ }^{9}$

U Vašingtonu su pažljivo pratili jugoslovenske poteze usmerene na šire ekonomsko otvaranje prema SSSR-u i prema vanblokovskim zemljama. Otpravnik poslova u američkoj ambasadi R. Lajl skrenuo je 3. jula 1962. pažnju načelniku jugoslovenskog Ministarstva inostranih poslova Jakši Petriću da će okupljanje nesvrstanih u Kairu na inicijativu Jugoslavije dodatno otežati nastojanja Stejt departmenta da spreči konačno usvajanje dvaju restriktivnih amandmana $u$ Kongresu uperenih direktno protiv Jugoslavije. ${ }^{10}$ Stavovi jugoslovenskih zvaničnika o potrebi organizovanog suprotstavljanja „imperijalističkoj“ politici industrijski razvijenih zemalja i učešće Kube na skupu čiji je „sponzor" Jugoslavija, po Lajlu, iskoristiće protivnici Jugoslavije u Kongresu da dokažu koliko je besmisleno pružati pomoć zemlji koja tesno sarađuje sa glavnim američkim ideološkim i vojnim protivnicima. ${ }^{11}$

Tokom susreta na Brionima, 3. avgusta 1962, sa američkim ambasadorom u UN Adlajom Stivensonom (Adlai Stivenson), ${ }^{12}$ Tito se osvrnuo na ekonomske implikacije Kairske konferencije i smisao borbe zemalja u razvoju za ukidanje „diskriminatorskog međunarodnog režima, nametnutog od vodećih svetskih sila“. Nerazvijene zemlje nisu u Kairu imale nameru da formiraju front protiv ZET-a (kako su to tumačili na Zapadu), već su se samo dogovorile o aktivnostima kojima će nastojati da utiču na velike sile da uvaže interese drugih zemalja, jer će se u protivnom "sebični kartel" tih sila sam od sebe srušiti „kao kula od karata“ - objasnio je Tito. Na Stivenso-

${ }^{9}$ Deklaracija konferencije o problemima ekonomskog razvoja, Skupovi nesvrstanih zemalja, Beograd 1974, 63-68.

${ }^{10}$ Dragan Bogetić, Uvođenje američkih ekonomskih restrikcija Jugoslaviji tokom 1962. Ukidanje statusa „najpovlašćenije nacije“, Istorija 20. veka, br. 1, Beograd 2009, 87-106.

${ }_{11}$ Diplomatski arhiv (DA), Ministarstva spoljnih poslova Republike Srbije (MSP RS), 1962, Politička arhiva (PA), SAD, f-119, 422 333. Zabeleška o razgovoru J. Petrića sa R. Lajlom, ministrom - savetnikom i otpravnikom poslova američke Ambasade 3. jula 1962.

${ }^{12}$ Do susreta je došlo na inicijativu Jugoslavije. Jugoslovenski MIP je smatrao da treba iskoristiti okolnost što Adlaj Stivenson provodi letnji odmor u krstarenju Mediteranom. Američkom ambasadoru Kenanu je predloženo da ovaj uticajni američki diplomata poseti Tita u njegovoj letnjoj rezidenciji. Ta inicijativa je prihvaćena, iako se nije uklapala u Stivensonov program krstarenja. - The National Archives (TNA), Foreign Office (FO) 371, CY 103 145/4, 163920. 
novo pitanje koliku štetu trpi Jugoslavija zbog politike ZET-a, Tito je odgovorio da njegova zemlja svake godine zbog toga gubi 30 miliona dolara. ${ }^{13}$

Stavove Jugoslavije u vezi sa ovom problematikom Tito je zvaničnicima iz Vašingtona pojasnio tokom svoje prve posete SAD i tokom razgovora sa predsednikom Kenedijem, 17. oktobra 1963. To je bila problematika u kojoj je Tito pokušao da se nametne kao državnik koji, zahvaljujući svom ugledu i uticaju u vanblokovskim državama, može da odigra ulogu važnog arbitra između njih i SAD. Kenedi je sa odobravanjem prihvatio jugoslovenske stavove o konkretnim oblicima ekonomske pomoći zemljama u razvoju, kako bi se obezbedili elementarni uslovi za konsolidaciju njihovih privreda i time smanjila unutrašnja politička nestabilnost, koja često dovodi do mešanja stranih sila u njihove unutrašnje stvari i širih međunarodnih sporova. Kenedi je u razmatranju ovog problema ukazao na određene teškoće sa kojima se Sjedinjene Države stalno suočavaju. Čak ni bogata država kao što je Amerika ne može finansirati program pomoći toliko brojnoj skupini nerazvijenih država, naglasio je Kenedi. Žalio se da u takvoj akciji vrlo slabo učestvuju ostale razvijene države. Samim tim, ma koliko bila obimna američka pomoć, kada se ona razdeli mnogobrojnim državama, ekonomski efekat je minimalan. Kada bi se ona koncentrisala na nekoliko država, onda bi se stvarno nešto moglo postići. Tito se složio sa ovakvom argumentacijom i objasnio Kenediju da se Jugoslavija zato zalaže za institucionalizovane oblike međunarodne pomoći zemljama u razvoju preko Ujedinjenih nacija. U tome je video i smisao održavanja Konferencije UN za trgovinu i razvoj, koja je trebalo da otpočne sa radom u proleće naredne godine. Tu konferenciju su inicirale neangažovane zemlje na osnovu odluke koje su te zemlje donele na Beogradskom samitu 1961. i na Kairskoj ekonomskoj konferenciji 1962. Iza tih inicijativa, u oba slučaja, stajao je Tito, jer je smatrao da bez ekonomske emancipacije, nesvrstane zemlje ne mogu obezbediti ni svoju političku i nacionalnu emancipaciju. Pored toga, Tito je izneo Kenediju svoj stav, koji namerava da zastupa i na predstojećem zasedanju Generalne skupštine UN, da bi finansijska sredstva koja su korišćena za vojne potrebe, a koja bi se oslobodila u slučaju uspeha pregovora o razoružanju, trebalo preusmeriti ka zemljama u razvoju, kao poseban vid međunarodne pomoći. ${ }^{14}$

Američki zvaničnici su, međutim, sa velikim rezervama pratili nastup predstavnika nesvrstanih zemalja u Ujedinjenim nacijama i prera-

${ }^{13}$ AJ KPR, I-3-a/SAD. Zabeleška o razgovoru druga Predsednika sa Adlaj Stivensonom, predstavnikom SAD u OUN i američkim ambasadorom u Beogradu Džordžom Kenanom prilikom prijema i ručka na Vangi, 3. avgusta 1962; TNA, FO 371, CY 103 145/4, 163920.

${ }^{14}$ FRUS, 1961-1963 Volume XVI, Eastern Europe, doc 162. Memorandum of Conversation; AJ KPR, I-2/SAD. Zabeleška o razgovorima Tito-Kenedi. Popodnevni razgovori. Latinska Amerika, 17. oktobar 1963; TNA, FO 371, NY 103 145/6, 172 002. U. S. Visit of President Tito. 
stanje tih zemalja u moćnu glasačku mašinu u Svetskoj organizaciji koja na sve načine želi da ograniči monopol velikih sila u donošenju svih ključnih odluka kojima su se regulisala burna zbivanja u međunarodnim odnosima. Kada je reč o ekonomskoj problematici, to je posebno došlo do izražaja tokom Konferencije Ujedinjenih nacija o trgovini i razvoju (UNCTAD), održanoj u Ženevi, od 23. marta do 16. juna 1964. Tim pre, što je UNCTAD postao glavni organ Generalne skupštine UN, u čijoj nadležnosti su bili problemi povećavanja obima trgovine, investicija i razvoja zemalja u razvoju, odnosno modaliteti podrške njihovim naporima da se integrišu u svetsku ekonomiju na ravnopravnoj osnovi. Zemlje u razvoju su u Ženevi uspele da pokrenu razmatranje niza pitanja značajnih za njihov položaj u svetskoj trgovini i privredi, da prvi put u Ujedinjenim nacijama nametnu svoju problematiku i razbiju dotadašnju blokadu razvijenih zemalja. Tada je 77 zemalja u razvoju (koje su, 15. juna 1964, formirale široku međunarodnu asocijaciju pri UN - poznatu kao Grupa 77), donelo deklaraciju u kojoj su iznele svoje poglede o budućim oblicima saradnje sa razvijenima. To je kasnije uticalo na dalju politiku Međunarodnog monetarnog fonda, kao i na uvođenje Opšte šeme preferencijala, čime je otvoren put njihovim proizvodima na tržišta razvijenih zemalja. Tokom 70-ih i 80-ih godina, UNCTAD je preuzeo značajnu ulogu u korenitoj transformaciji sistema međunarodnih ekonomskih odnosa. Formiran je upravo zato, jer se pokazalo da međunarodne ekonomske i finansijske institucije kao što su GATT (Opšti sporazum o carinama i trgovini), Međunarodni monetarni fond i Svetska banka nisu mogle dati adekvatan doprinos generalnom rešavanju problema zemalja $u$ razvoju i otklanjanju narastajućih dispariteta u svetskoj trgovinskoj razmeni. ${ }^{15}$

Problemi ekonomskog razvoja bili su prisutni i tokom samita nesvrstanih zemalja u Kairu, oktobra 1964. i tokom samita u Lusaki, septembra 1970. Međutim, s obzirom da je to bilo vreme kada među nesvrstanim zemljama nije postojao jedinstven stav o potrebi institucionalizacije njihove saradnje i zajedničkog i organizovanog nastupa u Ujedinjenim nacijama i široj sferi međunarodnih odnosa - efekat njihovih aktivnosti usmerenih na korigovanje aktuelnog svetskog ekonomskog poretka bio je zanemarljiv. ${ }^{16}$

Ovakva situacija se bitno menja početkom 70 -ih godina, tokom razdoblja kada dolazi do stvaranja pokreta nesvrstanosti i sve energičnijeg delovanja prvih institucionalnih mehanizama te asocijacije. To je bilo vreme kada se nesvrstane zemlje na međunarodnoj sceni i u Ujedinjenim naci-

${ }^{15}$ Godišnjak Instituta za međunarodnu politiku i privredu. 1964, 80-81, 909-942; Leo Mates, Konferencija UN o trgovini i razvoju, Međunarodni problemi, 3/1964, 49-113; Božidar Frangeš, Jugoslavija i konferencija UN o trgovini i razvoju, Beograd 1964; UNCTAD VI: Background and issues, May 1983, ODI Briefings 4.

${ }^{16}$ Dragan Bogetić, Tito i nesvrstani. Iskušenja na putu stvaranja asocijacije vanblokovskih država, Zbornik radova Tito: viđenja i tumačenja, Beograd 2011, 405-416. 
jama nameću kao autonomni, homogeni i kolektivni politički faktor sa izraženim ekonomskim interesima i nezaobilazan subjekt međunarodnog ekonomskog sistema, prema kome su i Sjedinjene Američke Države morale sada pokazati daleko više respekta nego ranije. Istovremeno, to je ujedno bilo i vreme kada nesuglasice Beograda i Vašingtona oko jugoslovenskog koncepta radikalne transformacije postojećeg sistema međunarodnih ekonomskih odnosa, posebno dobijaju na intenzitetu. Takav trend naročito je došao do izražaja tokom održavanja samita nesvrstanih u Alžiru, septembra 1973, na kome je pokrenuta inicijativa za održavanje posebnog zasedanja Generalne skupštine Ujedinjenih nacija, posvećenog isključivo problemima ekonomskog razvoja i premošćavanja sve većeg jaza koji je delio bogati Sever od siromašnog Juga. ${ }^{17}$ Jugoslavija je, kao jedna od najeksponiranijih država po pitanju neophodnosti uspostavljanja novog međunarodnog ekonomskog poretka, smatrala da je ovaj koncept realan, jer izražava interese ne samo zemalja u razvoju nego i razvijenih zemalja. Polazilo se od jednostavne ekonomske računice, sačinjene početkom 70-ih godina, u vreme kada dolazi do dramatične eskalacije energetske krize i do ispoljavanja različitih manifestacija svetske ekonomske krize $\mathrm{u}$ industrijskim zemljama i SAD - narastajućom inflacijom, recesijom, nezaposlenošću, negativnim saldom u platnom bilansu i opadanjem životnog standarda. Polazište jugoslovenske računice, ipak, bilo je u duhu Marksove teorije o tendencijskom padu profitne stope, obrazložene u Kapitalu u sklopu Marksove ekonomske analize protivrečnosti sa kojima se suočava privreda zapadnih zemalja. U tom smislu, interes razvijenih zemalja da prihvate programske smernice koncepta novog međunarodnog ekonomskog poretka proizilazio bi iz savremene realnosti sa kojom se suočava svetska privreda. Naime, u duhu ovakvog tumačenja, u sklopu aktuelnog međunarodnog ekonomskog sistema, apsorpciona moć tržišta Trećeg sveta i platežna moć zemalja u razvoju stalno se sužava, stalno opada. S druge strane, proizvodnja razvijenih zemalja stalno se uvećava, stalno raste, u skladu sa ekonomskim imperativima koje nameće zakon proširene reprodukcije. Dakle, raskorak između ponude i tražnje na svetskom tržištu se stalno uvećava (ponuda raste, tražnja opada) što je, po računici jugoslovenskih ekonomista, moralo, u bližoj ili daljoj budućnosti, izazvati opštu, globalnu ekonomsku krizu, poput one iz 1929. godine, koja je dovela do kraha tadašnjeg međunarodnog ekonomskog poretka, ali i do izbijanja novog svetskog rata. Ukoliko su razvijene zemlje zainteresovane da obezbede plasman svojih proizvoda na svetskom tržištu, neophodno je bilo da preduzmu odlučne mere radi jačanja i diverzifikacije privreda zemalja u razvoju kao potencijalnih kupaca tih proizvoda. To je

${ }^{17}$ AJ, KPR, I-4-a/15. Informacija o IV konferenciji nesvrstanih zemalja; Izveštaj delegacije SFRJ o toku i rezultatima IV konferencije šefova država ili vlada nesvrstanih zemalja. 
podrazumevalo eliminisanje diskriminacije iz međunarodnih ekonomskih odnosa, podsticanje procesa industrijalizacije u zemljama u razvoju, reformu međunarodnog monetarnog sistema, potpunu suverenost nad prirodnim bogatstvom i dinamikom privrednog rasta, obezbeđivanje preferencijala nerazvijenim zemljama od strane razvijenih i to bez reciprociteta (kako $u$ robnoj razmeni, tako i u ostalim oblicima međunarodne ekonomske saradnje), pravo na nacionalizaciju u okviru prava na raspolaganjem sopstvenom privredom (kao i na obeštećenje u slučaju eksploatacije prirodnih bogatstava ovih zemalja od strane razvijenih zemalja), podsticanje razvoja tehnologije u zemljama $u$ razvoju i transfer tehnologije $u$ te zemlje, obezbeđenje međunarodne pomoći procesu razvoja privrede i društva zemalja u razvoju, bez posebnih političkih i drugih uslova (finansijska pomoć pod posebno povoljnim uslovima). ${ }^{18}$

Razvijene zemlje su prihvatile inicijativu nesvrstanih zemalja, uobličenu na Samitu nesvrstanih u Alžiru, o održavanju posebnog zasedanja Generalne skupštine UN posvećenog problemima ekonomskog razvoja. U tom duhu je u proleće 1974. održano VI specijalno zasedanje Generalne skupštine UN. To je bilo prvo vanredno zasedanje svetskog parlamenta posvećeno isključivo ekonomskoj problematici - sva prethodna vanredna zasedanja bila su posvećena političkim pitanjima. Na VI zasedanju Generalne skupštine usvojena je Deklaracija o uspostavljanju novog međunarodnog ekonomskog poretka i Program akcije. ${ }^{19}$ Sledeći korak u pravcu regulisanja problema zemalja u razvoju bilo je usvajanje Povelje o pravima i dužnostima država, na XXIX redovnom zasedanju Generalne skupštine UN, decembra $1974 .^{20}$

Iako je ideja o nužnosti uspostavljanja novog međunarodnog ekonomskog poretka načelno prihvaćena, postojale su suštinske razlike $u$ interpretaciji puteva i metoda ostvarivanja ovog koncepta, odnosno razlike u sagledavanju stepena i dubine promene postojećeg sistema. Tu se ispoljavaju dva osnovna prilaza, koji će trajno dolaziti do izražaja tokom budućeg dijaloga Sever - Jug. Prvi su zastupale nesvrstane zemlje i zemlje u razvoju i on se svodio na nužnost usvajanja mera čiji bi cilj bilo korenito, radikalno menjanje postojećeg sistema međunarodnih ekonomskih odnosa i eliminisanje svih oblika diskriminacije i pritisaka u toj sferi, zasnovano na načelu ravnopravnosti i aktivnog učešća svih država nezavisno od njihove realne ekonomske i političke moći. Drugi prilaz, prvenstveno lansiran od zapadnih

${ }^{18}$ Dragan Bogetić, Nesvrstanost i novi međunarodni ekonomski poredak, Marksistička misao, br. 1, Beograd 1979, 159-176.

${ }^{19}$ Declaration on the Establishment of a New International Economic Order: United Nations Assembly document, A/RES/S-6/3201 of 1 May 1974.

${ }^{20}$ Charter of Economic Rights and Duties of States: United Nations General Assembly document A/RES/29/3281 of 12 December 1974. 
sila, insistirao je na tome da je sistem međunarodnih ekonomskih odnosa $u$ suštini dobar i da ga treba samo korigovati i okviru postojećih institucija i to putem pregovora zainteresovanih država oko lokalizovanja ekonomskih problema, ali ne i održavanjem svetske ekonomske konferencije uz učešće predstavnika svih zemalja.

Ipak, kooperativan nastup industrijski razvijenih zemalja tokom VI specijalnog zasedanja Generalne skupštine UN predstavljao je, nesumnjivo, pozitivan nagoveštaj u sklopu opštih nastojanja za rešavanjem ekonomskih problema sa kojima su se suočavale zemlje u razvoju. Ukupan domašaj takve strategije najviše je zavisio od buduće podrške američke vlade i spremnosti najmoćnije zapadne sile da se aktivno uključi u realizaciju osnovnih prioriteta na kojima se zasnivao koncept novog međunarodnog ekonomskog poretka.

Tokom celog posleratnog razdoblja, pa sve do 1973. i 1974. godine i prvih organizovanih akcija Grupe 77 u vreme opšte energetske krize - Sjedinjene Američke Države nisu ispoljavale veći stepen zainteresovanosti za rešavanje nagomilanih ekonomskih problema u svetskoj privredi i međunarodnoj trgovinskoj razmeni. Goruće protivrečnosti i disproporcije u svetskom ekonomskom sistemu tokom tog razdoblja, ostale su na margini američke međunarodne strategije prema nesvrstanom svetu. „U vreme VI specijalnog zasedanja UN, aprila 1974. godine, Sjedinjene Države nisu imale dobro definisan odnos prema pokrenutim pitanjima. Predstavnici SAD su branili postojeći ekonomski poredak i odbijali da uopšte razmatraju predloge o radikalnim promenama. Jedan o razloga je bio taj, da je usvajanje Deklaracije i Programa za akciju na VI zasedanju došlo u vreme kada su se važne političke promene odigrale u SAD i kada SAD jednostavno nisu bile spremne da formulišu nove inicijative“ ${ }^{21}$ Nepripremljenost SAD da na adekvatan način reaguju na nove događaje i promene u međunarodnim odnosima proizilazila je $\mathrm{u}$ velikoj meri iz njihove preokupiranosti izvlačenjem iz Vijetnamskog rata, angažovanjem u Bliskoistočnoj krizi i unutrašnjim potresima (Votergejtska afera). ${ }^{22}$

Počevši od 1973. godine, posebno u novim okolnostima u međunarodnim odnosima - podstaknutim odlukom Konferencije nesvrstanih zemalja u Alžiru o pokretanju globalnog programa i akcije za uspostavljanje novog međunarodnog ekonomskog poretka - dolazi do korenite i kompleksne promene u američkom prilazu nesvrstanosti. Odnosi Sever - Jug nameću se kao jedna od ključnih determinanti američke spoljne politike. Zvanični vladini stavovi, inicijative i akcije ne ograničavaju se više na sporadične,

${ }^{21}$ J. S. Singh, A New International Economic Order. Towards a Fair Redistribution of the World Resourses, Praeger Publishers, New York 1977, 13-14.

${ }^{22}$ D. Nikoliš, $n$. d., 70. 
kurtoazne, marginalne izjave o ulozi nesvrstanih zemalja u međunarodnoj politici, već poprimaju obrise jedne sve oblikovanije i sistematizovanije strategije. Stav SAD o konceptu novog međunarodnog ekonomskog poretka svodio se u početku na deklarativnu podršku toj ideji i bio prožet najavama spremnosti za angažovanjem $u$ prilog ekonomskog prosperiteta zemalja $u$ razvoju i protiv nejednakosti u ekonomskim odnosima. „Svetska zajednica“, izjavio je Kisindžer u UN, „ne može ostati podeljena između permanentno bogatih i permanentno siromašnih. SAD su spremne da se pridruže u ovom novom traganju. Mi ćemo učestvovati bez preduslova sa dobrom voljom i uz saradnju. Tražimo samo da drugi usvoje isti prilaz". ${ }^{23}$ Međutim, na VI specijalnom zasedanju Generalne skupštine UN, aprila 1974, na kome je konsenzusom usvojena Deklaracija o NMEP-u i Program akcija za njegovo sprovođenje, stav SAD prema pokretu nesvrstanih zemalja sve više dobija na oštrini i stavljen je u direktnu vezu sa ekonomskim pitanjima - energetskom krizom i ekonomskom krizom u zapadnim zemljama. „Nijedna zemlja“ - izjavio je Kisindžer misleći na nesvrstane zemlje - „ili blok zemalja, ne može jednostrano oblikovati budućnost... Organizovanje grupe zemalja kao bloka će, pre ili kasnije, prouzrokovati da se potencijalne žrtve organizuju u kontrablok... Prenos sredstava iz razvijenih zemalja u zemlje u razvoju, neophodan svakoj nadi za progres, može se odvijati samo uz podršku tehnološki razvijenih zemalja. Politika pritiska i pretnji će potkopati unutrašnju osnovu ove podrške“. ${ }^{24}$

Predsednik Ford je na XXIX redovnom zasedanju Generalne skupštine, septembra 1974, isto tako stavio naglasak na navodnu opasnost od "tiranije većine" - većine koju čine nesvrstane zemlje i zemlje u razvoju u UN i drugim međunarodnim telima. „Većina mora voditi računa o stvarnim interesima manjine da bi odluke većine bile prihvaćene“. U tom smislu je napomenuo: „Mi koji verujemo u pravilo većine i živimo od njega, moramo uvek biti na oprezu prema opasnosti od tiranije većine“. Angažovanje SAD na rešavanju svetskih ekonomskih problema Ford je uslovio kooperativnijim prilazom proizvođača nafte $u$ pogledu cena tog artikla i drugih sirovina i otvoreno upozorio „da će na zloupotrebe i korišćenje robe za političke ciljeve biti odgovoreno pritiscima i da svet ekonomske konfrontacije ne može biti svet političke saradnje“. ${ }^{25}$

${ }^{23}$ H. Kissinger, A Just Consensus, A Stable Order, A Durable Peace, An Address made before the 28th Session of United Nations General Assembly, September 24, 1973, Department of State Bulletin, October 15, 1973, 472.

${ }^{24} \mathrm{H}$. Kissinger, The Challenge of Interdependence, Statement made before the Sixth Special Session of the United Nations General Assembly, April 15, 1974, Department of State Bulletin, May 6, 1974, p. 477.

${ }^{25}$ AJ, KPR, I-3-a/107-212. SAD i politika nesvrstavanja; G, Ford, A Framework of International Cooperation, An Address made before the 29 th Session of the United Nations General Assembly, September 18, 1974., Department of State Bulletin, October 7, 1974, p. 446. 
U Beogradu su posebno negativnu reakciju izazvale otvorene pretnje američkog predstavnika u UN, Skalija, na XXIX redovnom zasedanju Generalne skupštine - da bi SAD mogle obustaviti finansiranje Ujedinjenih nacija, istupiti iz te organizacije i zatražiti da ona bude dislocirana sa američke teritorije zbog „bezobzirnog nametanja odluka i antiameričkog nastupa zemalja u razvoju“. U jugoslovenskim političkim krugovima ocenjeno je da „u osnovi ovakvog stava leži suštinsko neprihvatanje izmenjenih odnosa u svetu i nastojanja nesvrstanih zemalja i zemalja u razvoju za uspostavljanjem međunarodne saradnje na principima ravnopravnosti, poštovanja suvereniteta i integriteta svih država“. ${ }^{26}$ Zabrinutost SAD zbog mogućnosti slabljenja sopstvenog uticaja u Ujedinjenim nacijama i zbog mogućnosti sprovođenja u delo koncepta novog međunarodnog ekonomskog poretka poprimila je izokrenut vid navodne zabrinutosti za sudbinu Generalne skupštine UN i Ujedinjenih nacija, uopšte. „Svrha Generalne skupštine, i kao sigurnosnog ventila, i kao instrumenta međunarodne saradnje, je potkopana. Tragično, prvenstvene žrtve toga će biti one zemlje koje traže da osvoje ono što suštinski može biti njihovo ako bi nastavile u duhu saradnje (sa SAD). Moralni uticaj koji bi Generalna skupština trebalo da vrši ugrožen je i može biti uništen ako bi vlade, posebno one koje su njeni glavni finansijeri izgubile poverenje $u$ organizaciju... Odlučni smo da suprotstavimo tendencijama koje bi po nama nepopravljivo potkopale efikasnost Ujedinjenih nacija... Radi se o slabijim članovima organizacije koji bi najviše izgubili. Njima su Ujedinjene nacije potrebnije nego snažnijim silama kao što su Sjedinjene Države koje mogu prosperirati unutar ili izvan ove institucije... Podrška američkog naroda Ujedinjenim nacijama biće značajno oslabljena ako ne preovlada fer plej i brojčana većina ne poštuje poglede manjine“ ${ }^{27}$

Uporedo sa ovako oštro koncipiranim napadima na nesvrstane zemlje, povremeno su, ipak, provejavali afirmativni i tolerantniji stavovi američkih zvaničnika prema nesvrstanim zemljama i određeno razumevanje za njihove poglede. To je posebno došlo do izražaja tokom Kisindžerove posete Indiji i Jugoslaviji u jesen 1974, u sklopu njegove evropsko-azijske turneje. U Nju Delhiju, Kisindžer je izjavio da „Sjedinjene Države prihvataju nesvrstavanje. U stvari, Amerika teži svetu slobodnih, nezavisnih, suverenih država, koje će odlučno raditi u svom nacionalnom interesu. Podrška nacionalnoj nezavisnosti i raznolikosti koja to prati postala je centralna tema američke spoljne politike“. U istom izlaganju Kisindžer je napomenuo da „odnosi sa nesvrstanim zemljama predstavljaju jedan od stubova naše spoljne politike“ i da će se stav SAD „prema nesvrstanima bazirati na principima jednakosti, međusobnog poštovanja i podeli zajedničkih napora,

\footnotetext{
${ }^{26}$ AJ, KPR; I-3-a/107-215. SAD i OUN; AJ, KPR, I-4-c/2-20.

${ }^{27}$ H. Kissinger, Department of State Bulletin, August 4, 1975, p. 154.
} 
odnosno na gledištu da sve zemlje imaju udela u miroljubivom svetu“. Kisindžer je izneo stav da „prevlast, hegemonizam i sfere uticaja predstavljaju istorijske anahronizme" i da su zato "moralno i politički neodržive“. Iz toga je izveo zaključak da „blokovska diplomatija ma koje vrste predstavlja anahronizam bez izgleda na uspeh" ${ }^{28}$

Tokom razgovora sa Titom i jugoslovenskim rukovodstvom u Beogradu, 4. novembra 1974, Kisindžer je odao priznanje jugoslovenskoj politici nesvrstavanja i njenom aktivnom doprinosu većem razumevanju među narodima u traganju za miroljubivim rešavanjem međunarodnih problema i sukoba. Istakao je „da SAD poštuju nezavisnost Jugoslavije, uključujući i nezavisnost od SAD“ i „da se ovo može rešiti u prilično širokim okvirima... da saradnja bude dugoročna". ${ }^{29}$

Iako su jugoslovenske vlasti pozitivno ocenjivale Kisindžerove izjave u Nju Delhiju i Beogradu, one, ipak, nisu imale nikakvih iluzija da se tu radi o značajnijoj promeni američke međunarodne strategije ili nagoveštaju promene odnosa te sile prema politici nesvrstavanja. Kisindžerov nastup tumačen je kao svojevrsna manifestacija „određenog taktiziranja“ prema Indiji i Jugoslaviji zbog njihovog ogromnog uticaja u pokretu nesvrstanosti. ${ }^{30} \mathrm{U}$ posebnom elaboratu Službe za spoljna pitanja jugoslovenskog Ministarstva inostranih poslova, naslovljenom "Sjedinjene Američke Države i politika nesvrstavanja“, elaboriran je stav da su Amerikanci došli do saznanja „da politika direktne i otvorene konfrontacije i otvorenih pritisaka na nesvrstane zemlje nije dala očekivane rezultate“ i da su „SAD započele preispitivanje svog taktičkog prilaza nesvrstanim zemljama, ostajući pri svojim osnovnim načelima - razbijanju jedinstva nesvrstanih zemalja i eliminisanju nesvrstanosti kao međunarodne politike koja se suprotstavlja američkim vitalnim interesima“. U tom cilju „prema svim nesvrstanim zemljama SAD primenjuju snažno izraženu selektivnu politiku. Nastoje da neke značajnije nesvrstane zemlje vežu što više za sebe i kanališu ih na usku regionalnu politiku i pružanje podrške američkim inicijativama kada je to moguće, izolujući ih od celine međunarodnih događaja. Teže da smanje uticaj i aktivnost nesvrstanih na međunarodnom planu i da kroz bilateralnu saradnju sa nekima od njih otupe oštricu njihove antiimperijalističke borbe“ ${ }^{31}$

${ }^{28}$ Borba, 30. oktobar 1974; AJ, KPR, I-3-a/107-212. Prvi komentari na govor Kisindžer-a u Nju Delhiju.

${ }_{29}$ AJ, KPR; I-3-a/107-215. Zabeleška o razgovoru Predsednika SFRJ J. B. Tita sa Državnim sekretarom SAD H. Kisindžerom, održanim 4. novembra 1974. godine; Beleška o razgovoru predsednika SIV-Džemala Bijedića sa Državnim sekretarom SAD dr H. Kisindžerom, 4. XI 1974.

${ }^{30}$ AJ, KPR, I -5-c/14-19. Predstojeća poseta Kisindžera Jugoslaviji; AJ, KPR, I-3a/107-212. Prvi komentari na govor Kisindžer-a u Nju Delhiju.

${ }^{31}$ Isto 
U Vašingtonu su, s druge strane, bili nezadovoljni zbog toga što Jugoslavija zauzima suviše „radikalne stavove“ u pogledu američke spoljne politike i ne ispoljava dovoljno razumevanja u pogledu „vitalnih interesa SAD“. U tom smislu, iznoseći u Stejt departmentu svoju ocenu aktuelne međunarodne strategije Jugoslavije, američki ambasador u Beogradu, Malkolm Tun, ukazivao je na to da „iako su Jugosloveni pokazali novu svest i razumevanje za osetljive oblasti u američkoj spoljnoj politici“" treba shvatiti da će "jugoslovenska vlada uvek biti na komunističkoj liniji“, „da je Jugoslavija slobodna i nezavisna komunistička zemlja koja je ipak anti-imperijalistički nastrojena". Pored toga, procenjeno je da je celokupna spoljnopolitička strategija Jugoslavije u funkciji njenih nastojanja da zadrži i ojača svoju lidersku poziciju u pokretu nesvrstanosti: „Na primer, kada je pokret postao radikalniji, Jugosloveni su u obavezi da preuzmu neke radikalnije stavove kako bi održali svoju ulogu vođstva“".

Politički krugovi u Beogradu, opet, bili su svesni da stav SAD o blokovskom i militantnom karakteru pokreta nesvrstanih zemalja i dalje sve više dobija na oštrini. Američka retorika pri formulisanju i iznošenju stavova prema nesvrstanom svetu u to vreme nesumnjivo je predstavljala mešavinu iznijansiranih, izbalansiranih, ali često kontradiktornih i demagoških smernica, u velikoj meri prožetih pretnjom i apelom da se moraju uvažavati vitalni interesi industrijski najrazvijenije države u svetu i realnost koja počiva upravo na njenoj superiornosti.

Centralnu tezu američke strategije prema nesvrstanima činio je stav o „svrstanosti nesvrstanih" - procena da su nesvrstane zemlje u vreme bipolarnog detanta i smanjivanja napetosti u odnosima između Istoka i Zapada pristupile formiranju „trećeg bloka“. „Bili smo uznemireni“, izjavio je predsednik Ford prilikom posete Jugoslaviji, avgusta 1975, „neodgovornošću (misli na nesvrstane zemlje - D. B.) koja se odrazila u nekim diskusijama o životnim ekonomskim problemima u forumu Ujedinjenih nacija. Sve veće udaljavanje između razvijenih zemalja i zemalja u razvoju, može samo da povredi najbolje interese obe strane i da dovede $u$ opasnost izglede za rešavanje svetskih problema". ${ }^{33}$ Tokom razgovora sa Titom, koji su potom usledili, ponovo je ispoljio svoje nezadovoljstvo jedinstvenim nastup nesvrstanih u međunarodnim odnosima: „Sada su veći nego oba bloka. To je sada najveći blok... Mislim da podela sveta na blokove nije najbolji način za rešavanje problema. U današnjem svetu, ne može biti konfrontacije i vojne aktivnosti kakvu smo poznavali tokom Vaše i moje mladosti. Ja ću se posvetiti eliminaciji tih izvora sukoba koji mogu voditi do vojne konfronta-

${ }^{32}$ FRUS, 1969-1976, Volume E-15, Part 1, Documents on Eastern Europe, 19731976, Yugoslavia, doc 69.

${ }^{33}$ Zdravica Predsednika Forda, Borba, 3. avgust 1975. 
cije. To će biti naša orijentacija“. ${ }^{34}$ Narednog dana, tokom druge runde razgovora, Ford je još eksplicitnije skrenuo pažnju na odgovornost nesvrstanih zemalja za eskalaciju aktuelne energetske i ekonomske krize u svetu. Napomenuo je da su SAD permanentno imale „konstruktivan stav“ o pitanju saradnje sa zemljama u razvoju, da je politika njegove administracije oduvek bila da pomaže nerazvijenima i da će takav stav ta administracija zadržati i na narednom zasedanju Generalne skupštine. „Sadašnja kriza nije naša krivica. To je zbog ekstremnog povećanja cena nafte. Mi želimo da radimo da izbegnemo katastrofu... Mi smo posvećeni UN. Mi smo ostavili mnogo novca i vremena u toj organizaciji. Ali, ona ne može biti organizovana i kontrolisana od strane blokova". Na poznate optužbe da odgovornost za tešku ekonomsku krizu u svetu snose zemlje izvoznice nafte, nadovezao se Kisindžer, ukazujući na to da se ovde zapravo radi o „ideološkoj konfrontaciji“, o filozofskim raspravama lišenim konkretnog sadržaja i pokušaju da se uspostavi potpuno nov međunarodni ekonomski poredak upravljen direktno protiv interesa zapadnih sila. ${ }^{35}$

S obzirom na učestale izjave američkih zvaničnika u kojima se osuđuje formiranje bloka nesvrstanih zemalja, ali i sve brojnije optužbe na račun politike nesvrstanosti generalno, za Jugoslaviju je bilo izuzetno značajno to što je u zajedničkom jugoslovensko-američkom saopštenju povodom razgovora Tito-Ford ponovo potvrđen „trajni interes Sjedinjenih Američkih Država i njihova podrška nezavisnosti, integritetu i nesvrstanoj poziciji Jugoslavije“. U tom smislu zajednički kominike predstavljao je reafirmaciju principa bilateralne saradnje, koje su u formi posebne platforme (Vašingtonske deklaracije) usvojili Tito i Nikson 1971. godine i koji su činili osnovu saradnje dveju država tokom prve polovine 70 -ih godina. ${ }^{36}$

Posle susreta Tito-Ford u Beogradu, postepeno se napušta oštra retorika prema politici razvijenih zemalja, proizašla iz radikalnog prilaza rešavanja problema Sever - Jug. Umesto toga, akcenat se sada stavlja na razradu niza mera koje su trebale pomoći nesvrstanim zemljama da se nametnu kao poželjni i važni partneri razvijenom delu sveta i koje su trebale obezbediti zemljama $u$ razvoju što efikasnije uključivanje u međunarod-

${ }^{34}$ AJ, KPR, I-3-1/107-215. Stenografske beleške sa razgovora Predsednika Republike Josipa Broza Tita sa Predsednikom SAD, Njegovom ekselencijom gospodinom Geraldom R. Fordom, održanih 3. avgusta 1975. u Beogradu; FRUS, 1969-1976, Volume E-15, Part 1, Documents on Eastern Europe, 1973-1976, Yugoslavia, doc 73. Memorandum of Conversation, Belgrade, August 3, 1975.

${ }_{35}$ AJ, KPR, I-3-1/107-215. Stenografske beleške sa razgovora Predsednika Republike Josipa Broza Tita sa Predsednikom SAD, Njegovom ekselencijom gospodinom Geraldom R. Fordom, održanih 4. avgusta 1975. u Beogradu; FRUS, 1969-1976, Volume E-15, Part 1, Documents on Eastern Europe, 1973-1976, Yugoslavia, doc 74. Memorandum of Conversation, Belgrade, August 4, 1975.

${ }^{36}$ Zajednička jugoslovensko-američka izjava, Borba, 5. avgust 1975. 
nu podelu rada i međunarodne političke tokove. Da bi se to ostvarilo $u$ praksi i da ne bi, kao što je to do tada bio slučaj, sve ostalo „samo mrtvo slovo na papiru", u Beogradu je definisana nova strategija realizacije ekonomskog programa nesvrstanih zemalja. Radilo se, u stvari, o novom prilazu razvijenim zemljama čije je težište sada prebačeno sa konfrontacije na kooperaciju. Žestoke optužbe ustupile su mesto dijalogu, a ultimativni zahtevi zamenjeni su konstruktivnim inicijativama. Takva strategija modernizacije i osavremenjivanja programa nesvrstanih zemalja - po analogiji sa nastojanjima sovjetskog lidera Gorbačova da se prilagodi duhu vremena i uhvati korak s njime - kasnije je na Zapadu nazvana „perestrojka pokreta nesvrstanosti“.

Ironijom sudbine, taj koncept nesvrstanih, koji je velikim delom bio rezultat brojnih jugoslovenskih inicijativa i akcija unutar pokreta, dobio je konačnu fizionomiju tek na Konferenciji šefova država i vlada nesvrstanih zemalja u Beogradu, septembra 1989, neposredno uoči raspada jugoslovenske države. Tako je vreme kada je Jugoslavija nestala sa političke karte sveta ujedno bilo i vreme kada će se kao glavni prioritet pokreta nesvrstanosti nametnuti borba za uspostavljanje novog međunarodnog ekonomskog poretka.

\section{Dragan Bogetić}

\section{THE YUGOSLAV-AMERICAN DISPUTE OVER THE NEW INTERNATIONAL ECONOMICAL OREDER CONCEPT}

\section{Summary}

The article analyses the dispute between the Yugoslavia and the United States concerning the differences in answer to the growing economical problems in the first half of the 1970-ties. This political dispute was enhanced since the different strategies to overcome the gap between the industrial and non-developed countries were promoted. Being the part of the Non-aligned movement, Yugoslavia made its standpoint as promoter of the radical transformation in the actual international economical relations. This Yugoslav attitude led to the direct collision with the political views of the United States. The Washington officials accused the Yugoslav political leadership for not having the senses for its vital interests. After the period of dispute, a rapprochement came, between the Belgrade and Washington. 